\title{
Coupling between tectonic activity and diagenetic evolution of a clastic buried hill-a case study from Gubei low buried hill in Jiyang Depression of Bohai Bay Basin
}

\author{
Yelei Wang ${ }^{1} \cdot$ Longwei Qiu $^{1,2} \cdot$ Yongqiang Yang ${ }^{1,2} \cdot$ Wenhao $\mathrm{Xu}^{3} \cdot$ Danish Khan ${ }^{1} \cdot$ Yupeng Qiao $^{1}$
}

Received: 25 November 2020 / Accepted: 16 January 2021 / Published online: 28 January 2021

(C) The Author(s) 2021

\begin{abstract}
This paper aims to gain new insights into clastic buried hill reservoirs. For this purpose, the Permian sandstone reservoirs in the Upper Shihezi Formation, Gubei low buried hill, Jiyang Depression, was taken as the object. Referring to the evolution histories of reservoirs and tectonics, the diagenesis of the reservoirs and its coupling with tectonic activity were investigated, with the aid of techniques like core observation, casting sheet observation, scanning electron microscopy (SEM), cathode luminescence, electron probe, back scattering, fluid inclusion, and pore permeability tests. The results show that the Permian sandstone reservoirs in the Upper Shihezi Formation, Gubei low buried hill, Jiyang Depression, are low-porosity, low-permeability reservoirs with complex diagenesis. The diagenetic evolution sequence can be summarized as early feldspar corrosion/kaolinite cemention/early pyrite cemention $\rightarrow$ carbonate cemention/secondary enlargement of quartz $\rightarrow$ quartz corrosion/corrosion of quartz and its secondary enlargement $\rightarrow$ late calcite cemention $\rightarrow$ late pyrite cemention/carbonate corrosion/late feldspar corrosion/ corrosion of dissolvable miscellaneous matrix; compaction effect exists throughout the evolution process. The reservoirs went through (I) shallow burial epidiagenesis, (II) near-surface hydrothermal diagenesis, (III) deep burial alkaline diagenesis, and (IV) continuous burial acid diagenesis. The diagenetic evolution of these four stages is significantly affected by tectonic activities, and the article lists the evidence that diagenesis is affected by tectonic activity. The research results lay the basis for the prediction and evaluation of the Permian sandstone reservoirs in the Upper Shihezi Formation, Gubei low buried hill, Jiyang Depression, and shed new light on the exploration of tight sandstone reservoirs.
\end{abstract}

Keywords Diagenetic evolution · Upper Shihezi Formation · Gubei low buried hill · Jiyang Depression

\section{Introduction}

In recent years, buried hill oil and gas $(O \& G)$ reservoirs have attracted much attention from scholars and explorers, along with the growing demand and in-depth exploration of O\&G.

This article is part of the Topical Collection on Big Data and Intelligent Computing Techniques in Geosciences.

Yelei Wang

15610046181@163.com

1 School of Geosciences, China University of Petroleum, Qingdao 266580, China

2 Laboratory for Marine Mineral Resources, Qingdao National Laboratory for Marine Science and Technology, Qingdao 266071, China

3 Sinopec Shengli Oilfield, Dongying 257100, China
Previous explorations have discovered an abundance of buried hill O\&G reservoirs across China. In particular, the Bohai Bay Basin boasts numerous buried hill O\&G reservoirs, ranging from the large Archean metamorphic buried hill in Liaohe oil field to the carbonate buried hill in Baxian Depression, Huabei oil field.

The existing studies on buried hill reservoirs mainly tackle Archean and Proterozoic metamorphic buried hills, Mesozoic volcanic buried hills, and Mesoproterozoic and Lower Paleozoic carbonate buried hills (Deng 2017; Han et al. 2020; Hou et al. 2019; Raza et al. 2020). In the recent research on Upper Paleozoic clastic reservoirs, fruitful results have been achieved on the features of non-buried hill tight sandstone reservoirs (Jin et al. 2019; Tong et al. 2012). However, there is little report on Upper Paleozoic clastic buried hills. The few relevant studies merely explore the source rocks and their evolution (Wang et al. 2015; Wang et al. 2020), the accumulation model of coal gas and tight gas (Meng et al. 
2009), the petrological features of reservoirs, and the qualitative illustration of diagenesis (Xie et al. 2019). The reservoir quality of tight sandstones mainly controlled by detrital composition, depositional environment, sedimentary facies, burial temperatures, strata pressures, and the chemical composition and flowrate of the pore water (Worden and Burley 2003; Morad et al. 2010; Taylor et al. 2010; Bjørlykke and Jahren 2012; Bjørlykke 2014).

Drawing on the previous studies, this paper analyzes the diagenesis of the Permian tight sandstone reservoirs in Gubei low buried hill, Jiyang Depression, and discusses the coupling between buried hill tectonic activity and diagenetic evolution. The following analysis and testing methods were adopted to facilitate the research: core observation, casting sheet observation, X-ray diffractometry (XRD) (Hadi et al. 2019; Rathanasalam et al. 2019; Yan et al. 2020), scanning electron microscopy (SEM) (Al Owais and El-Hallag 2020; Merizgui et al. 2019; Wang et al. 2019), and energy spectrum analysis. The research results provide a reference for the exploration and development of clastic buried hills.

\section{Overview of the study area}

Located in the northeast of the Jiyang Depression, Bohai Bay Basin, Gubei low buried hill borders Chengdong Fault in the north, Gubei Fault in the south, and Guxi Fault in the west, and transits to Gubei Sag in the east. Overall, the depression is a south-dipping, NE-trending, nose-shaped fault block controlled by the Chengdong Fault, Gubei Fault, and Guxi Fault. In total, the depression covers an area of $200 \mathrm{~km}^{2}$ (Fig. 1a, b). Drilling results indicate that the Permian strata in Gubei low buried hill mainly include the Shanxi Formation, Lower Shihezi Formation, Upper Shihezi Formation, and Shiqianfeng Formation.

Previous studies have shown that the structural evolution of Gubei low buried hill can be divided into three stages: compressive reverse fault in the Indosinian period, extensional fault depression in the Yanshanian period, and the transition from compressive to extensional structure in the Yanshanianearly Himalayan period ( $\mathrm{Hu}$ et al. 2019). During the Indosinian period, the Yangtze plate subducted northward and collided with the North China plate. During this period, the formation and evolution of the Paleozoic structure of Gubei low buried hill were controlled by the left-handed shear stress in the NNW direction. Under the compression of the Indosinian movement, Gubei low buried hill undergone uplift and denudation. As a result, much of the upper part of the Shiqianfeng Formation and Upper Shihezi Formation in the Permian strata went missing. During the Yanshanian period, the collision between the Yangtze plate and the North China plate ended, such that the compressive reverse fault in the Indosinian period switch into a normal fault. During the
Himalayan period, a series of NE and near EW tensile faults were formed under the torsional tensile stress in the region, which eventually evolved into Gubei low buried hill.

In Gubei low buried hill, there is a set of meandering river sedimentary system in the Upper Shihezi Formation (Hu et al. 2019). A huge amount of reservoir sand bodies has developed on the microfacies of meandering banks and the remaining sedimentary microfacies on the bottom of rivers in the Kuishan section, the middle of the Upper Shihezi Formation. The cumulative thickness of sandstone reaches $54 \mathrm{~m}$. It is the target layer of $O \& G$ exploration and coring of the low buried hill (Fig. 1c). In the study area, the reservoirs are mostly buried deeper than $3500 \mathrm{~m}$, exhibiting poor physical properties. The diagenesis of the reservoir is a key controller of the O\&G accumulation.

\section{Results}

\section{Reservoir features}

In the study area, the Upper Shihezi Formation can be broken down into the Wanshan section, Kuishan section, and Xiaofuhe section from bottom to top. The reservoirs mainly exist in the sandstone of the Kuishan section, accounting for $78 \%$ of the thickness of the reservoir. Only a few reservoirs belong to the other two sections.

The reservoir lithology is dominated by coarse sandstone and gravel-bearing coarse sandstone, which take up $81 \%$ of the total thickness of the reservoir. Medium sandstone and fine sandstone account for about $12 \%$ of the total thickness. Siltstone and argillaceous siltstone occupy a very small portion of the thickness.

The reservoir sandstone is mainly composed of lithic sandstone and sub-lithic sandstone (Fig. 2a). The mean contents of quartz, feldspar, and cuttings were determined through casting sheet observation. Under the microscope, the percentages of quartz, feldspar, and cuttings were observed as $77 \%, 9 \%$, and $14 \%$, respectively. The majority of the cuttings are metamorphic quartz. Therefore, the reservoir sand bodies are coarse, quartz-rich, feldspar-deficient, and pure.

A total of 8 wells were drilled in Gubei low buried hill to collect core samples of Permian sandstone. According to the porosity and permeability data of 630 samples, the porosity and permeability of the reservoir fall in the ranges of 1.5$16.3 \%$ and $0.01-9.275 \mathrm{mD}$, respectively. The mean porosity is about $9.11 \%$, while the mean permeability is around $2.13 \times$ $10-3 \mu \mathrm{m}^{2}$.

About $64.6 \%$ of all samples have a porosity between 5 and $10 \%$, and $51.6 \%$ have a permeability between 0.1 and $1.0 \mathrm{mD}$. Thus, the reservoir is highly heterogenous, with a poor correlation between porosity and permeability (Fig. 2b). In general, 


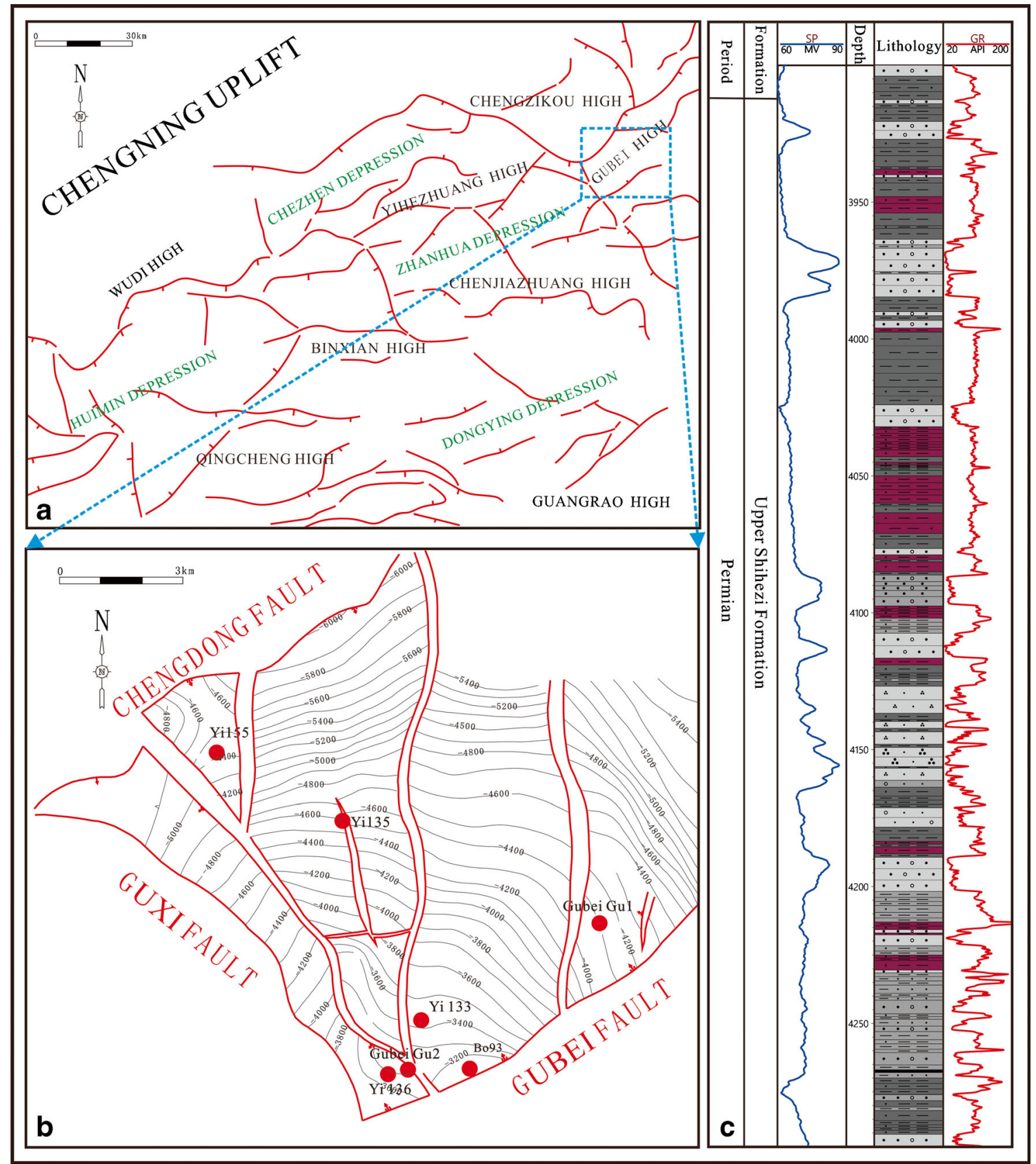

Fig. 1 The location $(\mathbf{a}, \mathbf{b})$ and stratum histogram (c) of Gubei low buried hill

the reservoir is a low-porosity, low-permeability tight sandstone reservoir (Fig. 2c, d).

\section{Reservoir diagenesis}

\section{Compaction}

In Gubei low buried hill, the Permian sandstone of the Upper Shihezi Formation is currently buried deeper than $3500 \mathrm{~m}$, a sign of strong compaction. According to statistics under the microscope, the total quartz content (grains
+ metamorphic quartz cuttings) is as high as $91 \%$, and the total quartz content averages at about $89.7 \%$. These highly rigid particles enhance the compaction resistance of the reservoir. But the mechanical compaction is amplified by the large buried depth. The strong compaction is mainly manifested by the compressive deformation of plastic particles (mica) (Fig. 3a), the pseudo-hybridization induced by the extrusion of plastic particles (Fig. 3b), and the linear-concave-convex contacts between rigid particles. According to the statistics on the extinction features, $17 \%$ of the quartz particles buried at $4100 \mathrm{~m}$ in Gubei 
Fig. 2 a-d The features of Permian sandstone reservoir, Upper Shihezi Formation, Gubei low buried hill
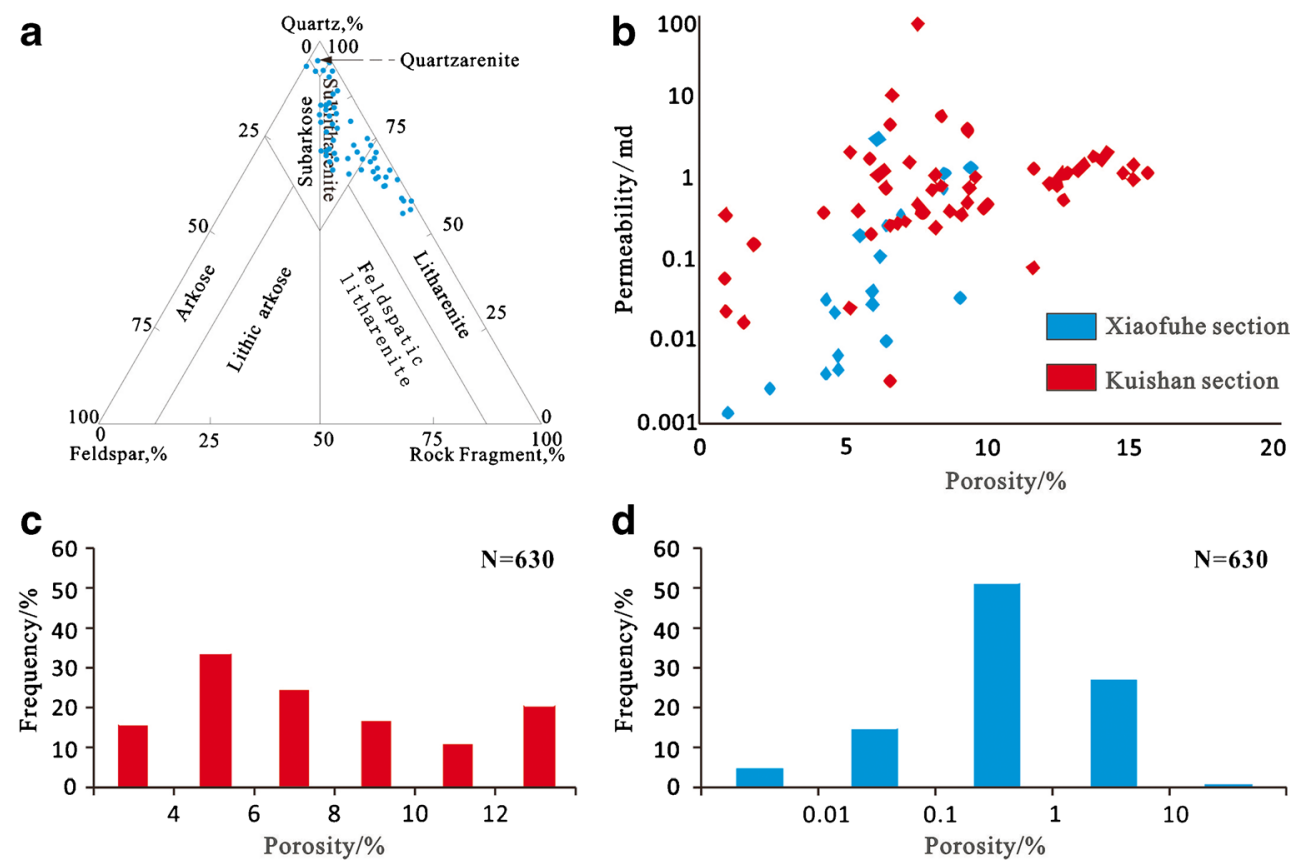

Gu-1 Well suffer from wavy extinction due to squeezing (Fig. 3c).

\section{Cemention}

Through casting sheet observation, cathodoluminescent sheet observation, SEM, and XRD on clay minerals, the cements in Permian sandstone reservoirs of the Upper Shihezi Formation, Gubei low buried hill, mainly consists of calcite cement, iron calcite cement, clay mineral cement, pyrite cement, and authigenic quartz. These cements differ greatly in content. The specific features of each cement are detailed below.

Carbonate cemention The relatively few carbonate cements are concentrated in local areas in the study area. The Kuishan section is the carbonate-rich section, which contains coarsegrained quartz sandstone. This section has a high content of carbonate cements, for $\mathrm{Ca}^{2+}$-rich fluids can easily pass through and precipitate in this section under the high original porosity of the sand bodies.

In the study area, carbonate cemention mainly involves two types of rocks: coarse-grained/micrite iron calcite or micrite calcite. Coarse-grained/micrite iron calcite was mostly developed in the corrosion pores of feldspar or intergranular pores of kaolinite (Fig. 3d), indicating that iron calcite was formed after a period of strong corrosion. Due to the large growth space, the coarse-grained iron calcite crystals reached up to $500 \mu \mathrm{m}$ and partly metasomatized the surrounding quartz. These crystals appeared dark red in the cathodoluminescence image (Fig. 3f), belonging to the first phase carbonate cement.
The micrite calcite was mostly filled between the grains or on the edge of early iron calcite (Fig. 3e) and partly metasomatized the surrounding feldspar. These crystals appeared bright yellow in the cathodoluminescence image (Fig. 3f), belonging to the second phase carbonate cement.

The two kinds of carbonates have a sharp content difference. Coarse-grained/micrite iron calcite accounts for $87 \%$ of the total carbonate cements, while micrite calcite accounts for only $13 \%$. Compared with the second phase carbonate cement, the first phase carbonate cement is relatively large in scale and complete in crystal forms.

Pyrite cemention The Upper Shihezi Formation in Gubei low buried hill is very rich in Permian pyrite cements. Large-scale pyrite cemention can be observed in the area of the Gubei Gu1 Well. This means the diagenetic environment in the study area is reductive or affected by hydrothermal activities.

According to sheet observation, the pyrite cements in the Upper Shihezi Formation either exist as a contiguous area of pyrite (Fig. 3h) or as nucleated pyrite cements (Fig. 3g). The former type of pyrite cements was filled in basal or porous form, and most particles were floating, suggesting that these cements belong to the first phase. The latter type of pyrite cements often grew in secondary pores or metasomatizes particles like quartz, belonging to the second phase of pyrite cement. The second phase pyrite cement is smaller in scale than the first phase pyrite cement.

Clay mineral cemention In Gubei low buried hill, the Permian clay mineral cements of the Upper Shihezi Formation mainly 
include kaolinite, chlorite, illite, and interstratified illite/smectite. XRD data show the large variations of these clay minerals in mass fraction (Fig. 4): the mass fraction of kaolinite falls in 5-65\%, averaging at $40.8 \%$; that of chlorite falls between 7 and $70 \%$, averaging at $27.6 \%$; that of illite falls in $0-51 \%$, averaging at $20.95 \%$; and that of interstratified illite/smectite falls between 0 and $29 \%$, averaging at $10.27 \%$.

Through casting sheet observation, cathodoluminescent sheet observation, and SEM, it can be observed that authigenic kaolinite was mostly filled in intergranular and corroded pores of feldspar. Its formation might be related to the corrosion of feldspar.

Kaolinite, which is widely distributed in the study area, appeared as plate-like or book-like aggregates under the SEM, exhibiting a good crystal form (Fig. 3i), and gave off a dark blue light in the cathodoluminescence image (Fig. 3o).

Despite its wide distribution in the study area, chlorite was poor in crystal form and mostly filled in pores. Under the SEM, a small number of scaly chlorites grew around quartz particles (Fig. 3k).

The study area has fewer illite and interstratified illite/ smectite than kaolinite and chlorite. XRD data show that the content of Permian interstratified illite/smectite in Gubei low buried hill changed between 0 and $40 \%$, reflecting the strong diagenesis in the study area. Under the SEM, illite and interstratified illite/smectite were distinctive for their filamentous or honeycomb shapes (Fig. 31).

Authigenic quartz In Gubei low buried hill, the Upper Shihezi Formation has a relatively low content of Permian authigenic quartz. The Gubei Gu-1 Well is the only place with developed authigenic quartz in good crystal form. This is attributable to the strong hydrothermal activity. Some of the authigenic quartz are produced as secondary enlargements. Their thickness peaked at $50 \mu \mathrm{m}$ (Fig. $3 \mathrm{~m}$ ) but exhibited a poor crystal form. Some are produced as quartz particles with good crystal form. SEM image shows that these particles often grew outside chlorite (Fig. 3n).

\section{Corrosion}

In Gubei low buried hill, the Permian reservoirs of the Upper Shihezi Formation have been transformed through alternating corrosions by acid and alkaline fluids. Many minerals were corroded to different degrees. The dominant corrosion actions are acidic corrosions of feldspar, tuff, and calcite cement. Besides, a few quartz and secondary enlargements fell victim to alkali corrosion (Fig. 3r). The corrosion greatly improves the physical properties of the reservoirs.

The corrosion of the Permian reservoirs takes place in two phases. The early corrosion is caused by the uplift of the Permian strata due to the Indosinian movement. As a result, the study area lacks the Triassic strata. In addition, the Shiqianfeng Formation of the Upper Permian System and the Xiaofuhe section atop the Upper Shihezi Formation were denudated to different degrees. During the $100 \mathrm{Ma}$ of shallow burial and exposure, feldspar corrosion induced by the leaching of atmospheric freshwater was the dominant form of corrosion. In the epidiagenesis process, the atmospheric freshwater washed away the excess $\mathrm{Al}^{3+}$ from the reservoirs, leaving some mold holes on feldspar. No kaolinite was precipitated inside these holes (Amel et al. 2015; Bi et al. 2019). This phenomenon is similar to the sandstone pores in the Permian Dongdingshan outcrop of Zibo, eastern China's Shandong province (Fig. 3p).

Strong corrosion also occurred during the phase of deep burial. The evidence is that the micrite calcite formed in the late stage was corroded, without being filled up by clay minerals like kaolinite (Fig. 3q). In the study area, the natural gas in the Permian reservoirs is generally attributed to the underlying Carboniferous coal-bearing strata (Wolela 2012). The hydrocarbon generation peaked in the early Himalayan period. This well explains the strong corrosion in the phase of deep burial.

\section{Diagenetic evolution sequence}

In Gubei low buried hill, the Permian reservoirs of the Upper Shihezi Formation are buried in a large depth range of 3670 $4700 \mathrm{~m}$. The bottomhole temperature is slightly higher than $160{ }^{\circ} \mathrm{C}$. The smectite content in interstratified illite/smectite is less than $15 \%$. The mean vitrinite reflectance RO stands at $1.75 \%$. According to the industry standard (2003) for dividing the diagenesis stages of clastic rocks, the current reservoirs have evolved to stage $\mathrm{B}$ of middle diagenesis.

Based on the observation of various diagenetic products, the filling, cutting, metasomatism between minerals, and the formation conditions of the minerals, the diagenetic evolution sequence of the study area can be summarized as early feldspar corrosion/kaolinite cemention/early pyrite cemention $\rightarrow$ carbonate cemention/secondary enlargement of quartz $\rightarrow$ quartz corrosion/corrosion of quartz and its secondary enlargement $\rightarrow$ late calcite cemention $\rightarrow$ late pyrite cemention/ carbonate corrosion/late feldspar corrosion/corrosion of dissolvable miscellaneous matrix; compaction effect exists throughout the evolution process. Note that different diagenetic processes overlap each other, due to the long time required for the formation of authigenic minerals and the principle of material balance (Yang et al. 2018).

\section{Discussion}

\section{Coupling between tectonic activity and diagenetic evolution}

Focusing on the history of structural evolution, the evolution process of reservoir diagenesis was summarized, in the light of 

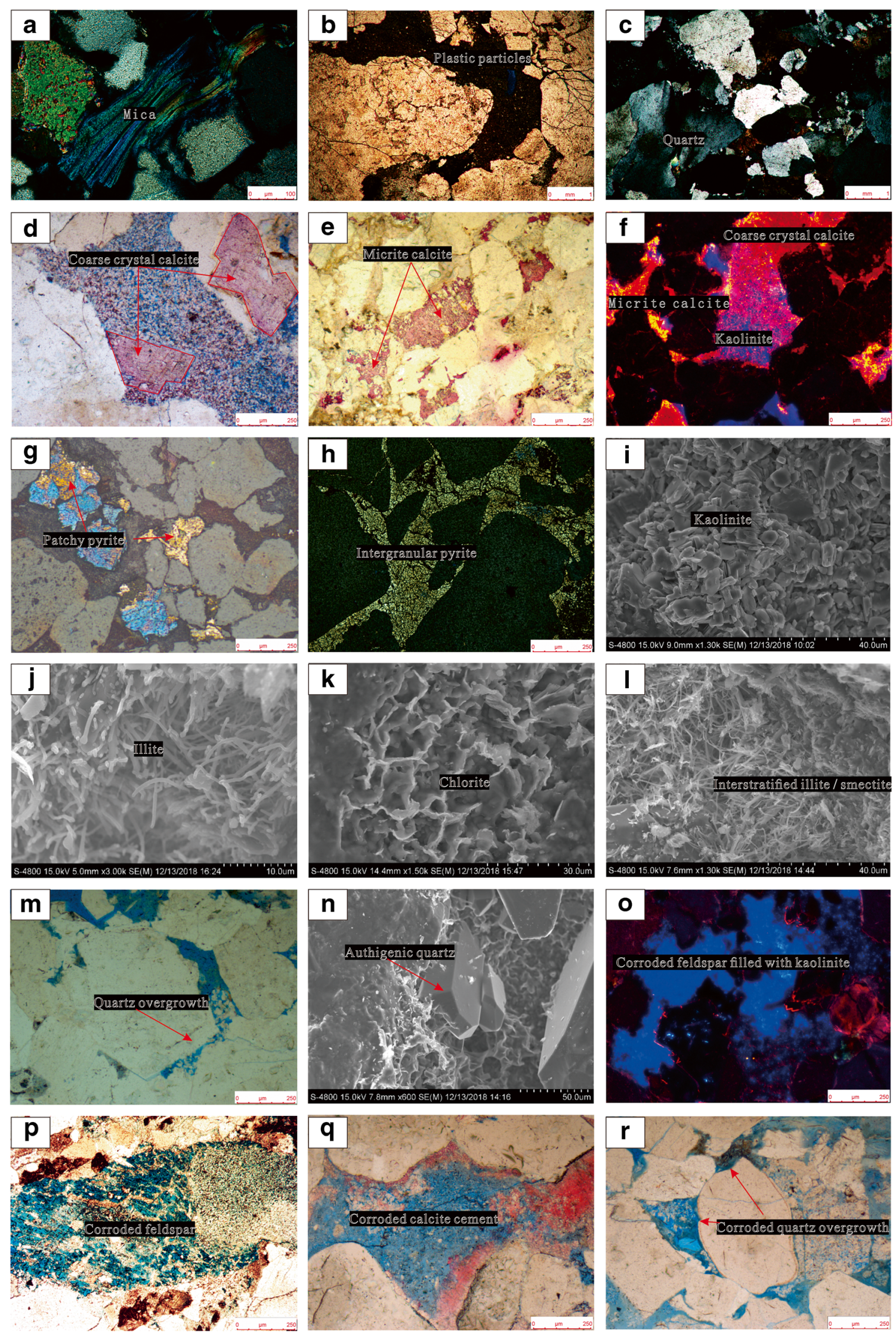
Fig. 3 The main diagenetic features of the Upper Shihezi Formation in the study area. a Linearly contacted particles and compressive deformation of mica, Gubei Gu-3 Well, 4084.7 m, orthogonal light. b Pseudo-hybridization of plastic particles, Gubei Gu-2 Well, $3520.1 \mathrm{~m}$, single polarized light. c Wavy extinction of quartz particles, Gubei Gu-1 Well, 4107 m, orthogonal light. d Coarse crystal calcite cement, Gubei Gu-2 Well, $3690.7 \mathrm{~m}$, single polarized light. e Micrite calcite cement between particles, Gubei Gu-1 Well, $4076.8 \mathrm{~m}$, single polarized light. f Corroded coarse-grained calcite filled with kaolinite, Gubei Gu-2 Well, $3690.7 \mathrm{~m}$, cathodoluminescence. g Patchy pyrite, Gubei Gu-1 Well, $4124.5 \mathrm{~m}$, reflected light. h Intergranular pyrite cement, Gubei Gu-1 Well, 4124.5 m, reflected light. i Plate-like kaolinite cement, Gubei Gu1 Well, 4075.6 m, SEM. j Filamentous illite, Gubei Gu-1 Well, 4076.8 m, SEM. k Leaf-shaped chlorite, Gubei Gu-1 Well, 4123.9 m, SEM. 1 Interstratified illite/smectite, mainly illite, Gubei Gu-1 Well, 4403 m, SEM. m Secondary enlargement of quartz, Gubei Gu-1 Well, 4124.5 $\mathrm{m}$, single polarized light. $\mathbf{n}$ Intergranular authigenic quartz, Gubei Gu-1 Well, 4125 m, SEM. o Corroded feldspar filled with kaolinite, Gubei Gu1 Well, $4125.6 \mathrm{~m}$, cathodoluminescence. p Corroded feldspar with kaolinite developed in the residual crystal, Gubei Gu-1 Well, $4123.9 \mathrm{~m}$, single polarized light. q Corroded calcite cement, Gubei Gu-1 Well, $4074.7 \mathrm{~m}$, single polarized light. r I, Gubei Gu-3 well, 4088.7 m, single polarized light

the changes in the diagenetic environment. Then, the coupling between reservoir diagenesis and tectonic activity was investigated. The O\&G reservoirs in the study area went through (I) shallow burial epidiagenesis, (II) near-surface hydrothermal diagenesis, (III) deep burial alkaline diagenesis, and (IV) continuous burial acid diagenesis.
Constrained by the diagenetic evolution sequence, the influence of each diagenetic stage on reservoir porosity was inverted. First, the initial porosity was calculated by the Trask sorting coefficient $\mathrm{So}(\mathrm{OP}=20.91+22.9 / \mathrm{So})$. Then, the porosity variation in each diagenetic stage was derived from the functional relationship between the surface porosity of the casting sheet and reservoir porosity. The relevant methods are not detailed here, because they are relatively mature in the study of diagenetic evolution (Van Dilla et al. 1989). This section aims to clarify the coupling between each diagenetic stage and tectonic activity.

\section{Shallow burial epidiagenesis stage}

After the deposition of the Permian reservoirs, the strata in the study area were uplifted significantly by the Indosinian movement. The Triassic stratum in the Jiyang Depression was completely denuded, exposing the Permian stratum. Thus, the reservoirs were shallow buried, creating an epidiagenesis environment. The formation fluids were mainly acid diagenetic fluids controlled by atmospheric freshwater.

In the study area, the Permian sandstone reservoirs of the Upper Shihezi Formation were transformed by epidiagenesis: the feldspar and carbonate components were corroded or dissolved by leaching and corrosion. The clay minerals (e.g., kaolinite) generated by feldspar corrosion migrated downward

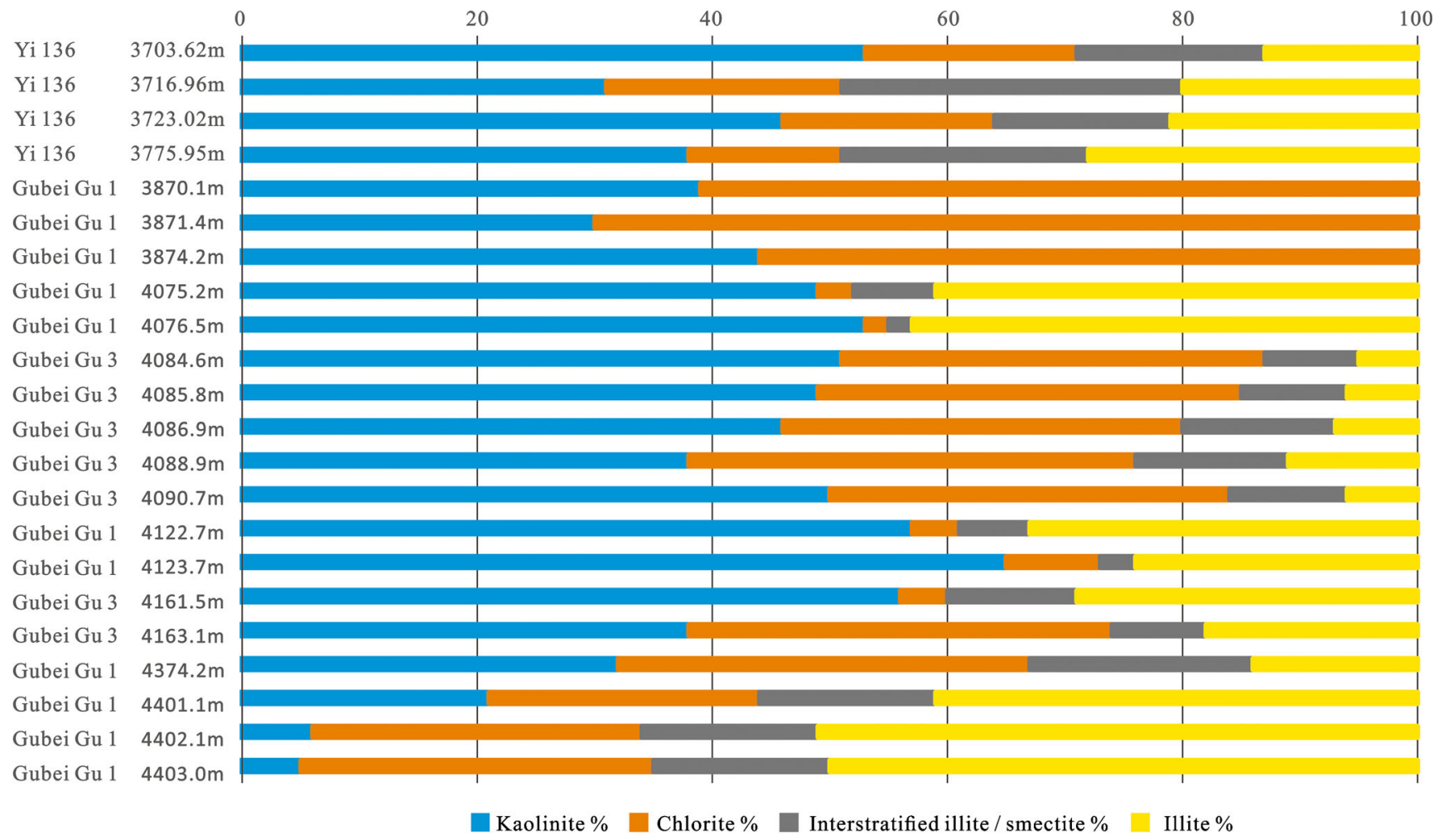

Fig. 4 The contents of the main clay minerals of the Upper Shihezi Formation in the study area 
and precipitated in the reservoir pores near the plane of unconformity.

From the statistics on feldspar content and clay mineral content below the plane of unconformity of the reservoirs, it can be seen that the reservoirs close to that plane have low feldspar content, high kaolinite content, large porosity, and large permeability (Fig. 5). The reason is that the pores of corroded feldspar are mostly filled with the associated kaolinite (Xiong et al. 2020). The kaolinite content of a stratum below the plane of unconformity is negatively correlated with the stratum-plane distance.

Previous studies hold that limonite infestation is the product of surface oxidation and a sign of epidiagenesis. Iron infestation was observed near the plane of unconformity, and the degree of infestation decreased with the distance to that plane. Overall, the mean porosity of the reservoirs was about $40 \%$ in the initial stage of burial, owing to the significant effect of compaction.

\section{Near-surface hydrothermal diagenesis stage}

Previous studies have discovered three sets of volcanic rocks developed in the Bohai Bay Basin: Carboniferous-Permian, Jurassic-Cretaceous, and Paleogene-Neogene. In the study area, diorite porphyrite is often developed within tens of meters above the Permian sandstone reservoirs of the Upper Shihezi Formation. Taking $3873.6 \mathrm{~m}$ of Gubei Gu-1 Well for example, the diorite porphyry was developed $30 \mathrm{~m}$ above the reservoir. The Ro value of nearby coal is as high as $6.28 \%$. A possible explanation is the promoting effect of intruding magma on the evolution of organic matter in this coal seam (Qian et al. 2020). From the mineral assemblage and the uniform temperature of fluid inclusions in the reservoir, it can be seen that the reservoirs in the study area have a wide range of pyritized phyllite, pyrite cement, siliceous cement, illite, and chlorite (Fig. 6), which were formed through mid-low temperature hydrothermal alteration. This mineral assemblage fills up the pores, reducing the reservoir porosity.

In addition, predecessors have already explored deep on the burial history of the study area, revealing that the maximum burial temperature is about $160{ }^{\circ} \mathrm{C}$. In the reservoirs of the study area, many secondary inclusions were developed with a uniform temperature of $185^{\circ} \mathrm{C}$. This is another evidence of the mid-low temperature hydrothermal alteration of the reservoirs (Fig. 6e). In this diagenesis stage, the mean reservoir porosity dropped from 40 to $19 \%$, due to the massive development of various cements.

\section{Deep burial alkaline diagenesis stage}

Previous studies have found two reasons for the formation of alkaline environment in the reservoir. First, the paleoclimatic conditions of the deposition process are arid and semi-arid, causing the evaporation to exceed recharge. The ensuing increase in the salinity and alkalinity of the water body gives birth to trona in sediments, resulting in alkali lake deposition. Second, during burial diagenesis, the acidic substances like organic acids, which are produced by the evolution of organic matters, quickly neutralize the alkaline formation water. A lot of acidic fluids are consumed in the reaction with carbonates and other minerals. Therefore, formation water carries alkaline features under certain conditions (Yu et al. 2019).

In the process of alkaline diagenesis, the most characteristic diagenesis phenomena in an alkaline environment are the corrosion of quartz particles and their secondary enlargement, the cemention and metasomatism of carbonate minerals, and the precipitation of chlorite. Although silica corrosion produced a few secondary pores, the porosity declined sharply due to the cemention and metasomatism of carbonate minerals and the heavy precipitation of illite and chlorite. These phenomena, coupled with the structural inversion in the Cretaceous era, the mean porosity of the sinking reservoirs dropped from 19 to $6.7 \%$ in this diagenesis stage.
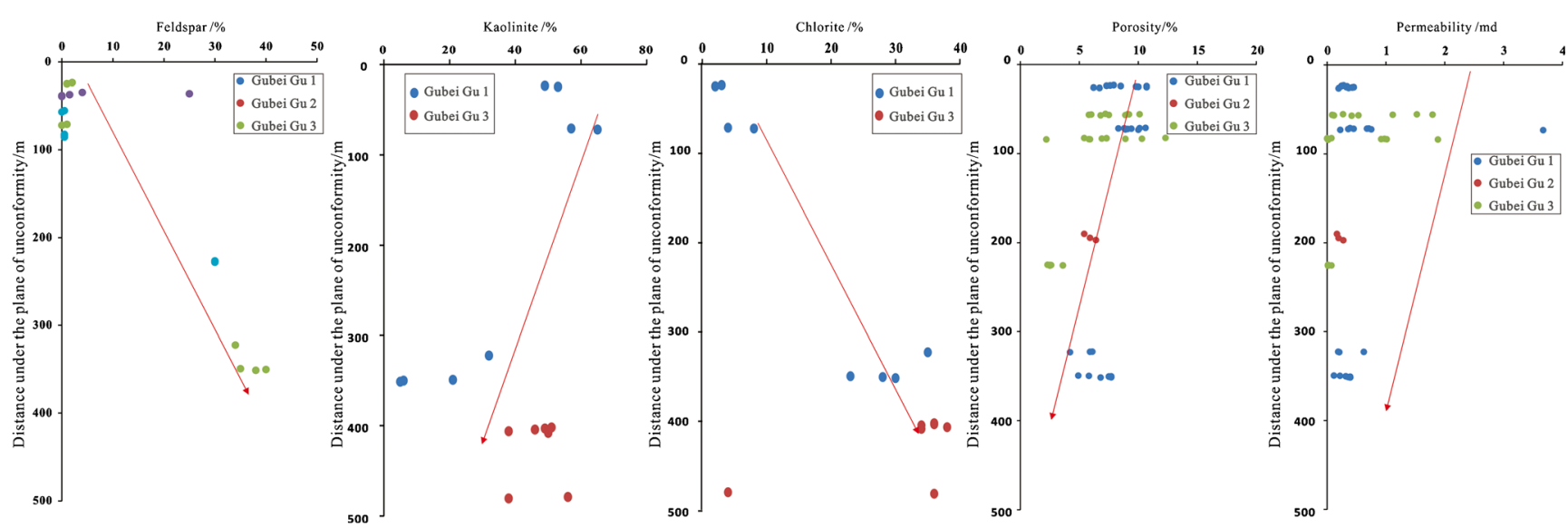

Fig. 5 The distribution of clay minerals and physical characteristics under the plane of unconformity in the Upper Shihezi Formation of the study area 

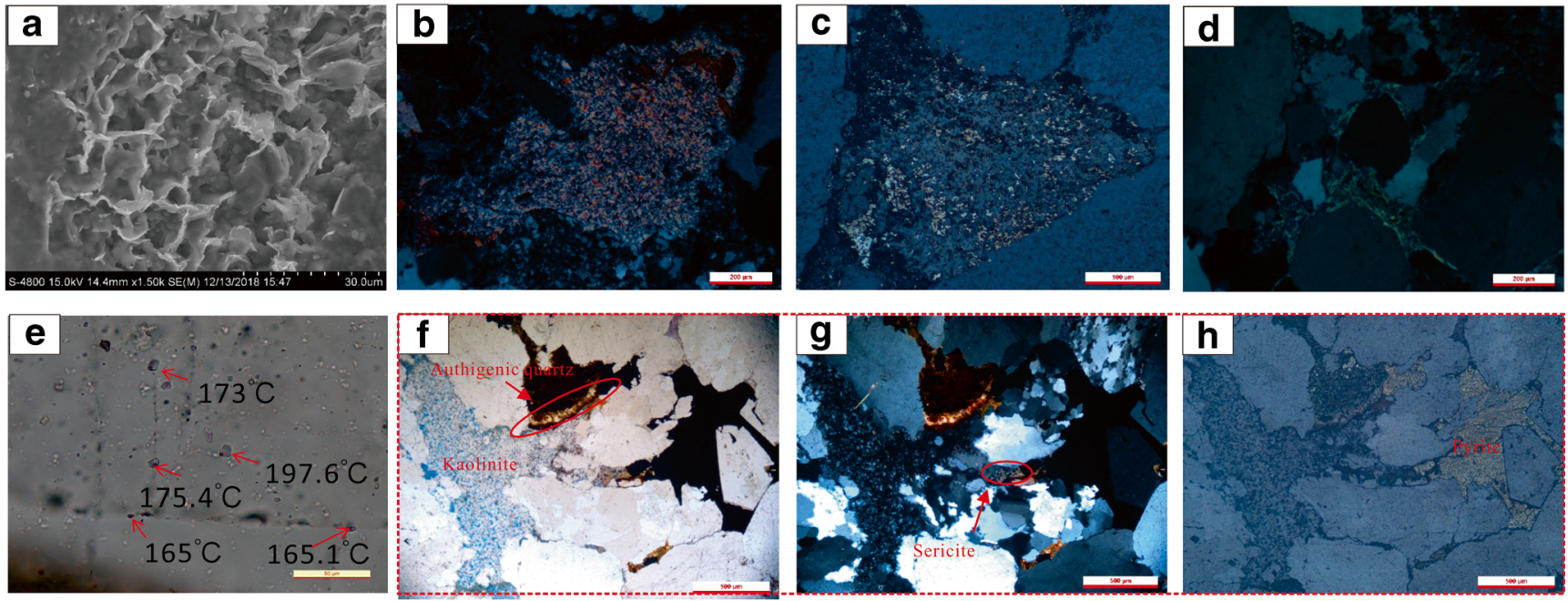

Fig. 6 The hydrothermal activity evidence of the Upper Shihezi Formation in the study area. a Leaf-shaped chlorite, Gubei Gu-1 Well, 4123.9 m, SEM. b Sericite, Gubei Gu-1 Well, 4076.8 m, orthogonal light. c Pyrite, Gubei Gu-1 Well, 4124.5 m, orthogonal light. d Illite, Gubei Gu1 Well, $4124.5 \mathrm{~m}$, orthogonal light. e Inclusions within the secondary

enlargement of quartz, Gubei Gu-1 Well, 4123.9 m, inclusion sheet under single-polarized light. $\mathbf{f}-\mathbf{h}$ Mineral assemblage of intergranular pores of kaolinite + pyrite cement + authigenic quartz + sericite, Gubei Gu-1 Well, $4124.5 \mathrm{~m}$, single polarized light + orthogonal light + reflected light.

\section{Continuous burial acid diagenesis stage}

Much research has been done on the burial and hydrocarbon generation history of the Carboniferous Permian source rocks in the study area (Teillet et al. 2019; Wang et al. 2020a). The predecessors agreed that the natural gas in the reservoirs of the study area was generated in two processes. The first process occurred at the end of the Mesozoic period, which generated a limited amount of gas and faced unfavorable preservation conditions. Thus, the first gas generation process contributes slightly to the reservoirs. After the reservoirs were deeply buried, the main gas generation process (the second process) occurred in the Dongying period. With the large generation volume and favorable preservation conditions, the second process contributes significantly to the coal gas reservoirs in the study area.

In the continuous burial acid diagenesis, the previously formed carbonates and other unstable substances (matrices) were corroded through hydrocarbon generation and acid expulsion. In the meantime, the Permian sandstone reservoirs in the study area suffered brittle fracturing under the strong tectonic activity of the Tertiary strata in the Jiyang Depression, creating lots of fractures. In this diagenesis stage, the corrosion improved the physical properties of the reservoirs to a certain extent and elevated the mean porosity from 6.7 to $9.1 \%$.

In summary, after the Permian reservoirs deposited in the study area, a large uplifting movement exposed the Permian strata, creating a shallow burial epidiagenesis environment. Then, the reservoirs went through beresitization due to lowtemperature hydrothermal alteration. After that, the reservoirs were buried deep continuously and transformed by alkaline diagenesis and acid diagenesis in turn. Eventually, the

reservoirs acquired the current features. On this basis, taking into account the geological periods/tectonic activity/diagenetic evolution sequence/macroscopic characteristics of diagenetic evolution and micro characteristics of diagenetic evolution, the authors established a geologic model of the coupling between tectonic movement and reservoir diagenesis (Fig. 7).

\section{Conclusions}

(1) In the Jiyang Depression, the Permian fluvial reservoirs of the Upper Shihezi Formation, Gubei low buried hill have mature sandstones, which are dominated by coarse sandstone and gravel-bearing coarse sandstone. The sand bodies are coarse, quartz-rich, feldspar-deficient, and pure.

(2) In the Jiyang Depression, the diagenesis of the sandstone in the reservoirs of the Upper Shihezi Formation, Gubei low buried hill can be divided into multiple types and stages. The diagenesis actions include compaction; the cemention of silica, pyrite, and clay minerals; the cemention of feldspar, quartz, and carbonates; and the corrosion of miscellaneous matrix.

(3) Based on the filling, cutting, metasomatism between minerals, and the formation conditions of the minerals, the diagenetic evolution sequence of the study area can be summarized as early feldspar corrosion/kaolinite cemention/early pyrite cemention $\rightarrow$ carbonate cemention/secondary enlargement of quartz $\rightarrow$ quartz corrosion/corrosion of quartz and its secondary enlargement $\rightarrow$ late calcite cemention $\rightarrow$ late pyrite cemention/carbonate corrosion/late feldspar corrosion/ corrosion of dissolvable miscellaneous matrix; compaction effect exists throughout the evolution process. 


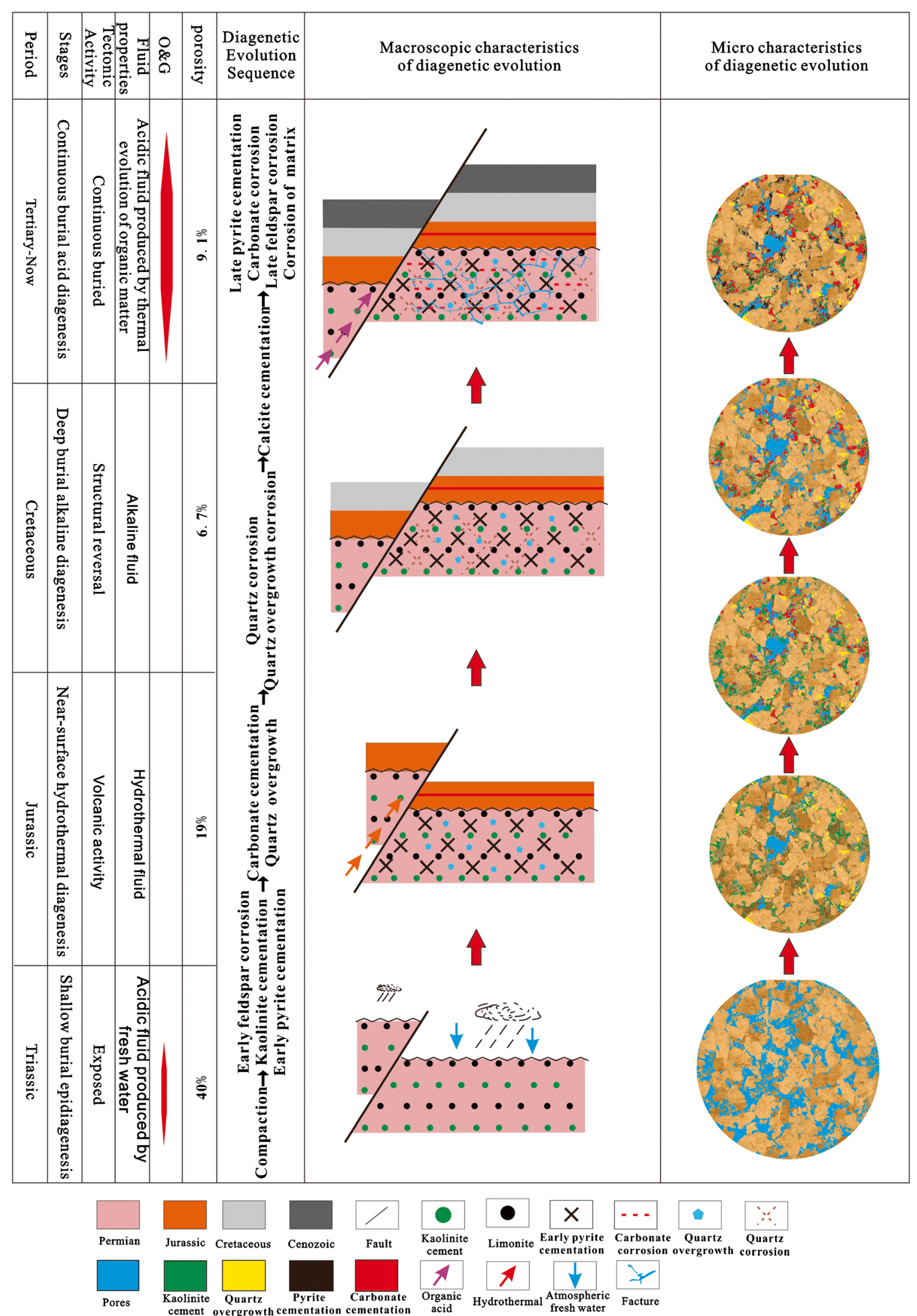

Fig. 7 The geologic model of the coupling between tectonic movement and reservoir diagenesis 
(4) Focusing on the history of structural evolution, the evolution process of reservoir diagenesis was summarized, in light of the changes in the diagenetic environment. Then, the coupling between reservoir diagenesis and tectonic activity was investigated. The O\&G reservoirs in the study area went through (I) shallow burial epidiagenesis, (II) near-surface hydrothermal diagenesis, (III) deep burial alkaline diagenesis, and (IV) continuous burial acid diagenesis.

(5) The quantitative inversion of pore evolution shows that in stages I and II, the reservoir porosity was mainly affected by compaction and cemention and dropped from 40 to $19 \%$. In stage III, the reservoirs were damaged, and the porosity fell from 19 to $6.7 \%$. In stage IV, the reservoir porosity rebounded from 6.7 to $9.1 \%$, due to corrosion alteration, and secondary corroded holes were developed and preserved well.

Aiming at the exploration of the Upper Paleozoic clastic buried hill O\&G reservoirs in the Jiyang Depression, comprehensive research on structural characteristics-sedimentationdiagenesis, comparing different diagenetic evolution, pore genesis, and differences in hydrocarbon-bearing properties. Studying the lithology, reservoir characteristics, pore formation mechanism, pore evolution mode, and distribution law of its high-quality reservoirs has important practical significance for reducing the exploration risk of Carboniferous-Permian clastic rock buried hill reservoirs in the Jiyang Depression. Therefore, this article is of great significance for $O \& G$ exploration.

Acknowledgements Thanks for the foundation support of "Genetic mechanism and development model of high-quality clastic rock reservoirs in the Upper Paleozoic in Jiyang Depression" under the major projects in the field of Sinopec's oil and gas exploration and development (Project No.: 30200018-17-ZC0613-0020). In addition, Yelei Wang especially wishes to thank his daughter, ZZ Wang, whose smile has given him powerful spiritual support over the past 2 years.

Open Access This article is licensed under a Creative Commons Attribution 4.0 International License, which permits use, sharing, adaptation, distribution and reproduction in any medium or format, as long as you give appropriate credit to the original author(s) and the source, provide a link to the Creative Commons licence, and indicate if changes were made. The images or other third party material in this article are included in the article's Creative Commons licence, unless indicated otherwise in a credit line to the material. If material is not included in the article's Creative Commons licence and your intended use is not permitted by statutory regulation or exceeds the permitted use, you will need to obtain permission directly from the copyright holder. To view a copy of this licence, visit http://creativecommons.org/licenses/by/4.0/.

\section{References}

Al Owais AA, El-Hallag IS (2020) Investigation of the nucleation process of electrodeposited nanostructured cobalt films using Brij 76 lyotropic liquid crystal. J New Mater Electrochem Syst 23(2):133138. https://doi.org/10.14447/jnmes.v23i2.a10
Amel H, Jafarian A, Husinec A, Koeshidayatullah A, Swennen R (2015) Microfacies, depositional environment and diagenetic evolution controls on the reservoir quality of the Permian Upper Dalan Formation, Kish Gas Field, Zagros Basin. Mar Pet Geol 67:57-71. https://doi.org/10.1016/j.marpetgeo.2015.04.012

Bjørlykke K, Jahren J (2012) Open or closed geochemical systems during diagenesis in sedimentary basins: constraints on mass transfer during diagenesis and the prediction of porosity in sandstone and carbonate reservoirs. AAPG Bull 96:2193e2214

Bjørlykke K (2014) Relationships between depositional environments, burial history and rock properties. Some principal aspects of iagenetic process in sedimentary basins. Sediment Geol 301, 1e14

Bi G, Lyu C, Li C, Chen G, Zhang G, Zhou Q, Li C, Zhao Y (2019) Impact of early hydrocarbon charge on the diagenetic history and reservoir quality of the Central Canyon sandstones in the Qiongdongnan Basin, South China Sea. J Asian Earth Sci 185: 104022. https://doi.org/10.1016/j.jseaes.2019.104022

Deng Y (2017) Formation and characteristics of large-medium buried-hill hydrocarbon reservoirs in Bohai Sea. Petroleum Research 2(2):97106. https://doi.org/10.1016/j.ptlrs.2017.07.001

Hadi MS, Saud SN, Hamzah E, Mamat MF (2019) Hydrogen embrittlement of 316L stainless steels exposed in 1.0M hydrochloric acid solution. Ann Chim Sci Mater 43(6):369-375. https://doi.org/10. 18280/acsm. 430602

Han C, Tian J, Hu C, Liu H, Wang W, Huan Z, Feng S (2020) Lithofacies characteristics and their controlling effects on reservoirs in buried hills of metamorphic rocks: a case study of late Paleozoic units in the Aryskum depression, South Turgay Basin, Kazakhstan. J Pet Sci Eng 191:107137. https://doi.org/10.1016/j.petrol.2020.107137

Hou M, Cao H, Li H, Chen A, Wei A, Chen Y, Wang Y, Zhou X, Ye T (2019) Characteristics and controlling factors of deep buried-hill reservoirs in the BZ19-6 structural belt, Bohai sea area. Natural Gas Industry B 6(4):305-316. https://doi.org/10.1016/j.ngib.2019. 01.011

Hu H, Jiang Y, Gluyas J, Zhao K, Fang J, Wang Y, Lu Y (2019) Mass transfer between sandstones and interbedded mudstones: impact on petroleum charge, Bohai Bay Basin, China. Mar Pet Geol 107:8198. https://doi.org/10.1016/j.marpetgeo.2019.05.007

Jin F, Wang X, Li H, Wu X, Fu L, Lou D, Zhang J, Feng J (2019) Formation of the primary petroleum reservoir in Wumaying inner buried-hill of Huanghua Depression, Bohai Bay Basin, China. Pet Explor Dev 46(3):543-552. https://doi.org/10.1016/S18763804(19)60034-0

Meng WG, Chen ZY, Li P, Guo YM, Gao XZ, Hui XF (2009) Exploration theories and practices of buried-hill reservoirs: a case from Liaohe Depression. Pet Explor Dev 36(2):136-143. https://doi. org/10.1016/S1876-3804(09)60116-6

Merizgui T, Hadjadj A, Kious M, Gaoui B (2019) Enhanced of electrical properties and shielding efficiency of hybrid composite with temperature. Revue des Composites et des Matériaux Avancés 29(6): 171-177. https://doi.org/10.18280/rcma.290604

Morad S, Al-Ramadan K, Ketzer JM, De Ros L (2010) The impact of diagenesis on the heterogeneity of sandstone reservoirs: a review of the role of depositional facies and sequence stratigraphy. AAPG Bull 94:1267e1309

Qian W, Yin T, Zhang C, Hou G, He M (2020) Diagenesis and diagenetic stages prediction of Ed2 reservoir in the west of Bozhong sag. Petroleum 6(1):23-30. https://doi.org/10.1016/j.petlm.2019.04.003

Rathanasalam V, Perumalsami J, Jayakumar K (2019) Effect of ultrafine ground granulated blast-furnace slag (UFGGBFS) and copper slag on ambient cured geopolymer concrete. Ann Chim Sci Mater 43(6): 377-382. https://doi.org/10.18280/acsm.430603

Raza M, Khan F, Khan MY, Riaz MT, Khan U (2020) Reservoir characterization of the B-interval of lower goru formation, miano 9 and 10, miano area, Lower Indus Basin, Pakistan. Environ Earth Sci Res J 7(1):18-32. https://doi.org/10.18280/eesrj.070103 
Taylor TR, Giles MR, Hathon LA, Diggs TN, Braunsdorf NR, Birbiglia GV (2010) Sandstone diagenesis and reservoir quality prediction: models, myths, and reality. AAPG Bull 94:1093e1132

Teillet T, Fournier F, Gisquet F, Montaggioni LF, Borgomano J, Villeneuve Q, Hong F (2019) Diagenetic history and porosity evolution of an Early Miocene carbonate buildup (Upper Burman Limestone), Yadana gas field, offshore Myanmar. Mar Pet Geol 109:589-606. https://doi.org/10.1016/j.marpetgeo.2019.06.044

Tong K, Zhao C, Lü Z, Zhang Y, Zheng H, Xu S, Wang J, Pan L (2012) Reservoir evaluation and fracture characterization of the metamorphic buried hill reservoir in Bohai Bay Basin. Pet Explor Dev 39(1): 62-69. https://doi.org/10.1016/S1876-3804(12)60015-9

Van Dilla MA, Dean PN, Fuscoe JC, Gray JW, Lucas JN, Peters DC, Trask BJ, van den Engh GJ (1989) Flow cytometric analysis and sorting of chromosomes. New Trends in Genetic Risk Assessment: 225-245. https://doi.org/10.1016/B978-0-12-388176-2.50024-2

Wang E, Liu G, Pang X, Li C, Wu Z (2020a) Diagenetic evolution and formation mechanisms of middle to deep clastic reservoirs in the Nanpu sag, Bohai Bay Basin, East China. Pet Explor Dev 47(2): 343-356. https://doi.org/10.1016/S1876-3804(20)60051-9

Wang J, Zhao L, Zhang X, Yang Z, Cao H, Chen L, Shan F, Liu M (2015) Buried hill karst reservoirs and their controls on productivity. Pet Explor Dev 42(6):852-860. https://doi.org/10.1016/S18763804(15)30082-3

Wang S, Wang G, Lai J, Li D, Liu S, Chen X, Yang K, Song L (2020) Logging identification and evaluation of vertical zonation of buried hill in Cambrian dolomite reservoir: a study of Yingmai-Yaha buried hill structural belt, northern Tarim Basin. J Pet Sci Eng 195: 107758. https://doi.org/10.1016/j.petrol.2020.107758

Wang ZJ, Li J, Ye PE, Wang CL, Cui XW (2019) Microstructure and hydration mechanism of autoclaved aerated concrete from fly ash. J New Mater Electrochem Syst 22(2):85-90. https://doi.org/10. 14447/jnmes.v22i2.a04
Wolela A (2012) Diagenetic evolution and reservoir potential of the Barremian-Cenomanian Debre Libanose Sandstone, Blue Nile (Abay) Basin, Ethiopia. Cretac Res 36:83-95. https://doi.org/10. 1016/j.cretres.2012.02.007

Worden RH, Burley SD (2003) Sandstone diagenesis: the evolution of sand to stone. In: Burley, S.D., Worden, R.H. (Eds.), Sandstone Diagenesis: Recent and Ancient, vol. 4. IAS Special Publication, pp. e44

Xie Y, Luo X, Wang D, Xu C, Xu Y, Hou M, Chen A (2019) Hydrocarbon accumulation of composite-buried hill reservoirs in the western subsag of Bozhong sag, Bohai Bay Basin. Natural Gas Industry B 6(6):546-555. https://doi.org/10.1016/j.ngib.2019.05. 002

Xiong Y, Tan X, Dong G, Wang L, Ji H, Liu Y, Wen C (2020) Diagenetic differentiation in the Ordovician Majiagou Formation, Ordos Basin, China: facies, geochemical and reservoir heterogeneity constraints. J Pet Sci Eng 191:107179. https://doi.org/10.1016/j.petrol.2020. 107179

Yan SQ, Wang QK, Wang HF, Qiu SL, Zeng ZQ, Fang Y (2020) Strength control factors of chlorite schist under schistose structure. Int J Des Nat Ecodyn 15(5):631-637. https://doi.org/10.18280/ ijdne. 150503

Yang T, Cao Y, Friis H, Wang Y, Zhou L (2018) Diagenetic evolution and chemical changes of deep-water mudstones of Shahejie Formation in the Dongying Sag, Jiyang Depression, Eastern China. Mar Pet Geol 93:14-32. https://doi.org/10.1016/j. marpetgeo.2018.02.005

Yu K, Qiu L, Cao Y, Sun P, Qu C, Yang Y (2019) Hydrothermal origin of early Permian saddle dolomites in the Junggar Basin, NW China. J Asian Earth Sci 184:103990. https://doi.org/10.1016/j.jseaes.2019. 103990 